\title{
A formação de professores e laicidade no ensino superior
}

\author{
The teacher's constitution and \\ the laity in the higher education
}

\author{
Carlos Roberto Jamil CURY1
}

\begin{abstract}
Resumo
Este artigo tem como objetivo refletir sobre a formação de professores em instituições de ensino superior à luz da laicidade. $\mathrm{O}$ ordenamento jurídico do Brasil, por meio de suas leis, normas, finalidades e objetivos da educaçáo, sustenta a laicidade como componente da formação docente em toda e qualquer instituição de ensino superior. Isso não significa nem uma postura antirreligiosa e nem a proibição de que as instituiçóes confessionais possam oferecer sua diferença sem imposição de valores.
\end{abstract}

Palavras-chave: Laicidade e Educação Superior. Formação de Professores e Laicidade. Legislação e Laicidade
Abstract

This article has as aim to examine the teacher's constitution in the higher education according to the principle of the laity. The Brazilian juridical order of education by their laws, rules, finalities and objectives sustains the laity as a component of the teacher's constitution in all the higher education institutions. This does not mean an anti-religious stance nor the prohibition that the confessional institutions can offer their difference without imposition of values.

Keywords: Laity and Higher Education. Teacher's Constitution and Laity. Law and Laity.

1 Doutorado em Educação: História, Política e Sociedade pela PUC/SP, Pós-doutor pela École des Hauts Études en Sciences Sociales, EHESS, França e pela UFRJ. Professor adjunto da PUC/ MG atuando na Graduaçáo e Pós-Graduação (mestrado e doutorado). Vice-presidente da SBPC. Endereço: Avenida Itaú, n. 505, 2o andar - PPGEducação/PUCMinas, Belo Horizonte/ MG, CEP: 30730-281. Tel.: (31) 34622884. Email: <crjcury.bh@terra.com.br>.

R. Educ. Públ.

Cuiabá

v. 27

n. $65 / 1$ p. $311-327$ maio/ago. 2018 
Este estudo tem como objetivo refletir sobre a formação de professores em instituiçóes de ensino superior à luz da laicidade. Apoiado no ordenamento jurídico do país, legislação e normas, em conceituação relativa ao tema, busca trazer argumentos que, respeitado o espaço privado da sociedade civil, sustentem a laicidade como componente da formação docente, seja nas instituiçóes públicas, seja nas instituiçóes particulares autorizadas.

A formação de professores, para atuarem como licenciados ou autorizados na Educação Básica, supõe, em qualquer Instituição de Ensino Superior, seja sob a forma de Universidade, Centro Universitário ou Instituição Isolada, a obediência ao Título VI da Lei de Diretrizes e Bases da Educação Nacional (lei n. 9.394/96) "Dos Profissionais da Educação (art. 61-67). Dispóe o art. 61:

Art. 61. Consideram-se profissionais da educação escolar básica os que, nela estando em efetivo exercício e tendo sido formados em cursos reconhecidos, são:

I - professores habilitados em nível médio ou superior para a docência na educação infantil e nos ensinos fundamental e médio;

II - trabalhadores em educação portadores de diploma de pedagogia, com habilitação em administração, planejamento, supervisão, inspeção e orientação educacional, bem como com títulos de mestrado ou doutorado nas mesmas áreas;

III - trabalhadores em educação, portadores de diploma de curso técnico ou superior em área pedagógica ou afim.

IV - profissionais com notório saber reconhecido pelos respectivos sistemas de ensino, para ministrar conteúdos de áreas afins à sua formaçáo ou experiência profissional, atestados por titulaçáo específica ou prática de ensino em unidades educacionais da rede pública ou privada ou das corporaçóes privadas em que tenham atuado, exclusivamente para atender ao inciso $\mathrm{V}$ do caput do art. 36 $\mathrm{V}$ - profissionais graduados que tenham feito complementação pedagógica, conforme disposto pelo Conselho Nacional de Educação.

Parágrafo único. A formação dos profissionais da educação, de modo a atender às especificidades do exercício de suas atividades, bem como aos objetivos das diferentes etapas e modalidades da educação básica, terá como fundamentos: I - a presença de sólida formação básica, que propicie o conhecimento dos fundamentos cientificos e sociais de suas competências de trabalho; 
II - a associação entre teorias e práticas, mediante estágios supervisionados e capacitação em serviço;

III - o aproveitamento da formação e experiências anteriores, em instituiçôes de ensino e em outras atividades. (BRASIL, 1996, grifos nossos).

Cumpre chamar a atenção, no caput, a expressão cursos reconhecidos e o inciso I do parágrafo único.

Quanto aos cursos reconhecidos, importa dizer que eles são uma atribuição privativa do Estado, seja para seus próprios cursos em suas instituições (art. $4^{\circ}$ da LDB), seja para as instituições privadas de qualquer natureza, sob o fundamento do art. 209 da Constituição Federal de 1988 e expresso nos art. 19 e 20 da LDB.

Por outro lado, todas as universidades e as outras formas de instituiçóes de ensino superior, no que concerne ao ensino, obedientes aos incisos I, II, III, VII e VIII do art. 206 da Constituição - princípios do ensino - são laicas, reproduzidos no art. $3^{\circ}$ da LDB. E isso se reforça com o art. 43 da LDB, que diz:

A educação superior tem por finalidade:

I - estimular a criação cultural e o desenvolvimento do espirito científico e do pensamento reflexivo;

II - formar diplomados nas diferentes áreas de conhecimento, aptos para a inserçáo em setores profissionais e para a participação no desenvolvimento da sociedade brasileira, e colaborar na sua formação contínua; III - incentivar o trabalho de pesquisa e investigação cientifica, visando o desenvolvimento da ciência e da tecnologia e da criação e difusão da cultura, e, desse modo, desenvolver o entendimento do homem e do meio em que vive;

IV - promover a divulgação de conhecimentos culturais, cientificos e técnicos que constituem patrimônio da humanidade e comunicar o saber através do ensino, de publicaçóes ou de outras formas de comunicação;

$\mathrm{V}$ - suscitar o desejo permanente de aperfeiçoamento cultural e profissional e possibilitar a correspondente concretização, integrando os conhecimentos que vão sendo adquiridos numa estrutura intelectual sistematizadora do conhecimento de cada geração;

VI - estimular o conhecimento dos problemas do mundo presente, em particular os nacionais e regionais, prestar serviços especializados à comunidade e estabelecer com esta uma relação de reciprocidade; 
VII - promover a extensão, aberta à participação da população, visando à difusão das conquistas e benefícios resultantes da criação cultural e da pesquisa científica e tecnológica geradas na instituição.

VIII - atuar em favor da universalizaçáo e do aprimoramento da educação básica, mediante a formação e a capacitação de profissionais, a realização de pesquisas pedagógicas e o desenvolvimento de atividades de extensão que aproximem os dois níveis escolares. (BRASIL, 1996, grifos nossos).

Nesse sentido, há uma reiteração de que a formação se dá com fundamentos cientificos e com o desenvolvimento do espirito cientifico.

As instituiçóes de ensino superior devem se pautar pelo Plano Nacional de Educação 2014-2024, que, em seu art. 2 ${ }^{\circ}$ IX acentua a valorização dos (as) profissionais da educação e se orienta pelas metas 15, 16, 17 e 18 do mesmo PNE e respectivas estratégias. Além desse dispositivo, elas devem seguir as Diretrizes Curriculares Nacionais, emanadas do Conselho Nacional de Educação, conforme disposto na lei n. 9.131/1995 e trazidas pelo Parecer CNE/CP n. 02/2015 e Resolução CNE/CP n. 02/2015. Esse Parecer e essa Resolução dirigem a formação inicial em nivel superior (cursos de licenciatura, cursos de formação pedagógica para graduados e cursos de segunda licenciatura) e para a formação continuada.

Essa importante Resolução, no seu art. $3^{\circ}, \mathbb{S} 5^{\circ}$, inciso $V$, diz que, entre outros, é princípio da formação docente: "V - a articulação entre a teoria e a prática no processo de formação docente, fundada no domínio dos conhecimentos científicos e didáticos, contemplando a indissociabilidade entre ensino, pesquisa e extensão."

$\mathrm{O}$ que difere as instituições públicas das privadas são as mantenedoras, que instituem e mantêm as suas diferentes instituições, segundo o art. 209 da Constituição e o art. 20 da LDB, e que podem oferecer uma diferença na constituição de seu projeto pedagógico, como, por exemplo, a oferta de cultura religiosa ou de história das doutrinas religiosas na formação geral dos seus estudantes.

Mas a formação docente deve pautar-se pelos fundamentos cientificos, considerando o desenvolvimento do espirito cientifico e assim poder possuir o dominio dos conhecimentos cientificos e didáticos.

Considerando-se, pois, tais fundamentos, indispensáveis inclusive para a autorização de funcionamento, vê-se que a universidade não é lugar do dogma que se caracteriza pela formulação doutrinária apresentada como indiscutível, certa e tida como verdade para todos. A universidade é lugar da circulação do saber crítico que reflete, analisa e questiona as condiçóes de produção de determinada 
realidade. Ela, pois, é chamada a desvendar as contradiçóes reais que assolam o senso comum e a própria vida social. Por essa via, qualquer realidade, como, por exemplo, o fenômeno religioso, pode ser objeto de estudos e pesquisas a partir das ciências humanas e sociais.

E a ciência é um desses campos que teve um desenvolvimento enorme na Modernidade por ter uma postura não dogmática e antidogmática no âmbito da terrenalidade. Essa postura, nas antípodas de todo e qualquer fundamentalismo ou dogmatismo, nasce de um confronto com princípios que por serem extrahumanos ou terrestres precondicionam a pesquisa e a vida política.

Historicamente, a passagem da concepção pré-moderna triádica e hierárquica (Deus - Homem - Mundo) cede lugar para uma concepção diádica (Homem Mundo), contendo dois movimentos: o do absoluto para o relativo (campo da terrenalidade) e o do absoluto para o campo do privado.

Em outro momento, Cury (2008, p. 127-128, grifo do autor) escrevia:

Deslocando o campo do sagrado e da fé para o privado e para o indivíduo, a Modernidade própria do Estado laico, no entanto, não adota a religião da 'irreligiáo' ou da antireligiosidade. Ao respeitar todos os cultos e não adotar nenhum, de um lado, o Estado se libera do controle religioso, e de outro lado, libera também as igrejas de um controle sobre suas especificidades no que toca ao campo religioso da fé e da crença. Isso quer dizer, pois, ao mesmo tempo, o deslocamento do religioso do estatal para o privado e a assunçâo da laicidade como um conceito referido ao poder de Estado que se afirma, por sua vez, como garante das liberdades próprias dos direitos civis. Assim, sob esse ponto de vista, a laicidade se coloca como um lugar de igualdade e de respeito às diferenças.

Pode-se assinalar alguns indicadores da laicidade. Tratase, por exemplo, no corpo legal, da liberdade religiosa, da expressão livre dos cultos, do caráter público dos cemitérios (abolindo o seu anterior caráter religioso mas deixar de considerá-los do modo mais respeitoso possível) e o controle dos mesmos pelo poder público. Fazem parte do mesmo contexto as leis relativas ao casamento civil, à possibilidade de divórcio e o atestado de óbito com os respectivos registros em cartórios civis.

A ciência, apanágio da universidade, procede de um mundo desencantado com relaçáo à religião, respeita os dogmas e a fé das pessoas e das correntes 
doutrinárias das religiôes, porém nos limites do espaço privado dos indivíduos e nos locais de culto.

A laicidade é um dos componentes mais fundamentais da Modernidade. Trata-se da separação da Igreja e do Estado e de aceitação da vida sociopolítica como autoprodução humana. Essa separação é condição para romper com uma visão organicista da sociedade em prol de uma concepção democrática. Em outros termos, vai-se do teocratismo hierárquico ao antropocentrismo democrático. Entre idas e vindas e contradiçóes, o domínio religioso na vida secular foi cedendo espaço para que o Estado assumisse a condição de autoridade e lugar de exercício do poder como representante do conjunto de cidadáos. Essa realidade de paradigmas gerou polêmicas quanto aos limites entre o livre exercício de crer e de cultuar e a autonomia dos cidadãos em se colocar como poder legítimo de fazer do contrato social a origem do poder e da ereção das leis.

A laicidade, então, implica o Estado como lugar do público, do comum, expressão de uma cidadania aberta em que a lei, a igualdade e a força não podem ser possuídas, nem por elementos extraterrenos, e nem por diferencialismos segregadores. Mas ela não é a religião da contrarreligião, respeitadora que é das crenças e dos cultos na sociedade civil. Náo por outra razão, a Lei de Diretrizes e Bases faz uma distinção importante, logo no seu art. $1^{\circ}$, entre a educação lato sensu (caput), de modo bastante abrangente, e a educação escolar (stricto sensu) em instituições próprias.

Art. $1^{\circ}$ - A educação abrange os processos formativos que se desenvolvem na vida familiar, na convivência humana, no trabalho, nas instituiçóes de ensino e pesquisa, nos movimentos sociais e organizaçóes da sociedade civil e nas manifestaçóes culturais.

$\$ 1^{\circ}$ - Esta lei disciplina a educação escolar, que se desenvolve, predominantemente, por meio do ensino, em instituiçóes próprias. (BRASIL, 1996).

Desse modo, a LDB reconhece a sociedade civil como um amplo lugar de educabilidade e, nesse caso, abrange as igrejas, aí incluídos seus meios próprios de comunicação e de informação.

A laicidade - campo próprio do político - implica tanto o republicanismo, cuja essência é, ex parte populi, poder decidir sobre as normas reguladoras da vida social. A Modernidade deixa de acatar a origem divina do poder terreno para, lentamente, definir a soberania popular como polo originário daquele poder. Com isso, a fé religiosa, respeitada no seu todo, desloca-se para o campo da sociedade civil, ou seja, no âmbito das instituiçôes privadas. No caso do Brasil, tal separação 
consta do art. 19 bem como a liberdade de pensamento, de consciência e de culto do art. $5^{\circ}$ da mesma da Constituição (BRASIL, 1988).

Mas isso não significa que a laicidade seja desprovida de valores. Bem ao contrário, o próprio respeito às doutrinas e à fé religiosas demonstra que toda a escolha pessoal, subjetiva e particular merece a consideração de todos. Além do mais, há dispositivos positivados no ordenamento jurídico que exigem de qualquer pessoa a obediência a parâmetros aí estabelecidos. É o caso, por exemplo, do art. $1^{\circ}$ da Constituição, que póe como fundamentos do Estado Democrático de Direito, entre outros, a cidadania e a dignidade da pessoa humana. ${ }^{2}$

Também o art. $3^{\circ}$ da Lei Maior, como que contrastando os fundamentos desse Estado com objetivos a serem atingidos à vista de uma realidade social desigual, póe como meta erradicar a pobreza e a marginalização social e reduzir as desigualdades sociais e regionais, e no caminho daquela dignidade, o do promover $o$ bem de todos, sem preconceitos de origem, raça, sexo, cor, idade e quaisquer outras formas de discriminação. E, no art. $4^{\circ}$, impóe como princípio das relações internacionais, entre outros, a prevalência dos direitos humanos e como decorrência o repúdio ao terrorismo e ao racismo. E o crime do racismo torna-se inafiançável pelo art. $5^{\circ}$, XLII. E, por trazer esse artigo, ele é uma longa lista dos direitos e deveres individuais e coletivos referidos tanto à cidadania (quando remete aos brasileiros) quanto aos direitos humanos (quando se reporta à pessoa).

No capítulo da educação, vale a pena transcrever todo o art. 205: "A educação, direito de todos e dever do Estado e da família, será promovida e incentivada com a colaboraçáo da sociedade, visando o pleno desenvolvimento da pessoa, seu preparo para o exercício da cidadania e sua qualificação para o trabalho" (BRASIL, 1988).

Para tanto, as Diretrizes Curriculares Nacionais da Formação Docente dispóem em nível superior, já citadas, no seu art. $3^{\circ}, \$ 5^{\circ}$, inciso II, que, entre outros, é princípio da formação docente:

II - a formação dos profissionais do magistério (formadores e estudantes) como compromisso com projeto social, político e ético que contribua para a consolidação de uma nação soberana, democrática, justa, inclusiva e que promova a emancipação dos indivíduos e grupos sociais, atenta ao reconhecimento e à valorizaçáo da diversidade e, portanto, contrária a toda forma de discriminação. (BRASIL, 2015).

2 A esse respeito, cf. CARVALHO, José Sérgio. Podem a Ética e a Cidadania serem ensinados? In: Pro-Posiçóes - UNICAMP, FE, v. 13, set/dez 2002 p. 157-168 e SARLET, Ingo Wolfgang. Dignidade da Pessoa Humana e Direitos Fundamentais na Constituiçáo Federal de 1988. Porto Alegre: Livraria do Advogado, 2001. 
Esse inciso é coerente com um dos considerando, espécie de preâmbulo das Diretrizes:

CONSIDERANDO a docência como ação educativa e como processo pedagógico intencional e metódico, envolvendo conhecimentos específicos, interdisciplinares e pedagógicos, conceitos, princípios e objetivos da formação que se desenvolvem entre conhecimentos cientificos e culturais, nos valores éticos, politicos e estéticos inerentes ao ensinar e aprender, na socialização e construção de conhecimentos, no diálogo constante entre diferentes visóes de mundo. (BRASIL, 2015, grifos nossos).

Com esse conjunto, pode-se afirmar que os valores laicos estão dispostos em dois níveis: um negativo e outro positivo, dialeticamente relacionados. Negativo no sentido da desconstruçáo dos preconceitos, das discriminaçóes com relação a indivíduos e a minorias e o da reduçáo das desigualdades sociais e das disparidades regionais. Positivo, no sentido da afirmação da tolerância, da aceitação e do reconhecimento.

A tolerância está expressa no art. $3^{\circ}$ da LDB, inciso IV como um dos princípios do ensino: respeito à liberdade e apreço à tolerância. A intolerância é a expressão de um dogmatismo nem sempre consciente em que se é intransigente com o pensamento divergente. $\mathrm{E}$ o inciso XII do art. $3^{\circ}$ toma princípio do ensino a consideraçâo com a diversidade étnico-racial. Diversidade sob tais parâmetros significa compartilhamento, diálogo. E, de novo, a Constituição e a LDB enfatizam a liberdade de aprender, o pluralismo de ideias e de concepçôes pedagógicas.

A aceitação é um passo além da tolerância pois implica uma adesão na receptividade do outro. Vai além de uma conformação. Posso conformar-me com uma situação posta, mas não preciso aceitá-la.

Finalmente, o reconhecimento é a confirmação do outro como livre, igual e sujeito dos mesmos direitos.

Em um livro no qual se estabelece um diálogo em sábia entrevista entre Maurizio Viroli e Norberto Bobbio é lembrado que há uma ética laica. No dizer de Bobbio e Viroli (2002, p. 67-68):

A caridade laica é também partilhar o sofrimento, mas é também desprezo contra aqueles que são responsáveis pelo sofrimento. É o desprezo que promove a força interior para lutar contra as causas do sofrimento. É exatamente porque quem não possui uma fé religiosa não vê qualquer valor no sofrimento que os homens padecem devido a outros homens e porque náo acredita na possibilidade ou no valor de um prêmio em 
outra vida, que a caridade laica procura, se pode, o remédio para o sofrimento, além de lenir o sofrimento do oprimido. Impele os oprimidos a combater a causa da opressão.

Além disso, continua Bobbio e Viroli:

[...] a república tem o dever de garantir a assistência, não como um ato de compaixão, mas como reconhecimento de um direito que deriva do fato de sermos cidadãos. (2002, p. 72). Afinal, os direitos sociais não foram um presente. Foram conquistados com lutas e sacrifícios, de homens e mulheres, crentes e não crentes que desejavam viver com dignidade suas vidas sobre a terra. (2002, p. 75-76).

\section{Ao que Bobbio responde (BOBBIO; VIROLI, 2002):}

Creio que você esteja contrapondo a justiça à caridade. Este é um grande tema da cultura laica. ... seria mais correto falar de senso de justiça que se expressa na exigência de modificar o estado das coisas através do direito. (p. 68), [...] já que os laicos não têm fé (p. 76). [...] A fé no homem é tudo. Nós somos homens em meio aos homens. Devemos encontrar aí o bem e o mal. A concepção laica da vida tem uma grande dignidade, mas não leva a cumprir obras de caridade. (p. 80).

E os laicos, dentro dos limites da razão, nos ensina Bobbio, diferentemente dos crentes católicos, que têm algo a oferecer a mais: "[...] não podem[os] prometer nada a quem cumpre desinteressadamente atos de serviço, senão a satisfação de ter cumprido um dever, o prazer de ter cumprido uma boa açáo. [...] senáo a satisfaçáo da consciência" (BOBBIO; VIROLI, 2002, p.70-71). Visto que a laicidade é um princípio que visa distanciar o Estado de valores que têm dogmas específicos dentro do jogo relativo da sociedade, visto que as igrejas podem exercer suas funçóes no interior da sociedade civil, cumpre assinalar um ponto bastante polêmico que toca à laicidade na história da educação brasileira. ${ }^{3}$ Tratase do ensino religioso, cujo caráter polêmico já existia no Império e se prolonga até hoje com a recente Concordata de Decreto n. 7.107/2010. ${ }^{4}$

3 Sobre a laicidade, cf. <www.edulaica.net.br> e A Educação Brasileira na primeira onda laica: do Império à República, disponível gratuitamente em pdf e e-book, na página <luizantoniocunha.pro.br>.

4 Cf. CURY, Carlos Roberto Jamil. Ensino Religioso na escola pública: o retorno de uma polêmica. Revista Brasileira de Educaçáo, Campinas, n. 27, p. 183-191, 2004. 
Conformado durante o Império, à luz da religião oficial do Estado Imperial e sob a guarda do Padroado, ele era disciplina constante dos currículos, afora outros dispositivos, como o juramento, o clero secular como membros do funcionalismo público pelo qual percebiam a côngrua e a permissão de cultos não católicos apenas em espaços privados. ${ }^{5}$ A Constituição Republicana de 1891 determinou a exclusão desse ensino nas escolas públicas, consoante o $\$ 6^{\circ}$ do art. 72 , por sinal, congruente com a separaçáo da Igreja e do Estado, seja do Decreto n. 119-A de 1890, seja pelo dispositivo do $\$ 7^{\circ}$, art. 72 .

Alguns Estados, ao longo da Velha República, fizeram retornar o ensino religioso nas escolas públicas e, apesar dos esforços da bancada católica na Revisão Constitucional de 1925/1926, ele não foi aprovado. ${ }^{6}$ Contudo, após a Revolução de Trinta, esse ensino foi reintroduzido por Getúlio Vargas e Francisco Campos pelo Decreto 19.941 de 1931.

A partir daí, esse ensino sempre constou das Constituiçóes desde 1934, seja como de oferta obrigatória e de matrícula facultativa $(1946,1967,1988)$, seja como de matrícula e de oferta facultativas (1937). Esses dispositivos determinaram que tal ensino comparecesse nas leis de diretrizes e bases (lei n. 4.024/61 e suas redaçôes dadas pela lei n. 5.692/71 e 7.044/82 e lei n. 9.394/96), ora restrita ao ensino primário (ensino de $1^{\circ}$ grau ou ensino fundamental), ora estendida ao ensino secundário (ensino de $2^{\circ}$ grau ou ensino médio).

No caso da atual LDB, o ensino religioso procedente do art. $210, \mathbb{\text { único }}$ da Constituiçáo, foi estabelecido no art. 33, sendo o primeiro artigo que sofreu alteração legal logo em $1997 .^{7}$

E é por conta desse artigo que comparece a formação de docentes para atuar nas redes públicas de ensino. Pelo art. 33 (original), sem ônus para os cofres públicos, a formação desses docentes caberia, no caso de ensino confessional, às respectivas igrejas ou entidades religiosas. No caso de ser interconfessional, caberia às diversas entidades religiosas.

Sobre esse assunto a Câmara de Educação Básica, com base na lei n. 9.131/95, por meio do Parecer n. CNE/CEB 5/97, já anunciava: "A Lei nos parece clara,

5 Cf. a respeito CURY, Carlos Roberto Jamil. Cidadania Republicana e Educaçáo: governo provisório do Mal. Deodoro e Congresso Constituinte de 1890-1891. Rio de Janeiro : DP\&A, 2001, especialmente, capítulos III, IV e XI.

6 Cf. CURY, Carlos Roberto Jamil. A educaçáo na revisão constitucional de 1925-1926. Bragança Paulista: EDUSF, 2003. 142 p.

7 Sobre esta modificação, consulte-se, de Luiz Antônio Cunha: O veto transverso de FHC à LDB: o ensino religioso nas escolas públicas, Educaçáo e Pesquisa. São Paulo, v. 43, n. 3, jul/set 2016. Consta também na página disponível em <luizantoniocunha.pro.br> . 
reafirmando o caráter leigo do Estado e a necessidade de formação religiosa aos cuidados dos representantes reconhecidos pelas próprias igrejas" (CONSELHO NACIONAL DE EDUCAÇÃO, 1997). ${ }^{8}$

Atendendo a essa versão original do art. 33 e ainda na sua vigência, o Conselho Nacional de Educação, por meio de seu Conselho Pleno, exarou o Parecer CNE/ CP n. 5/97, cujo teor merece ser conhecido:

[...] por ensino religioso se entende o espaço que a escola pública abre para que estudantes, facultativamente, se iniciem ou se aperfeiçoem numa determinada religiáo. Desse ponto de vista, somente as igrejas, individualmente ou associadas, poderão credenciar seus representantes para ocupar o espaço como resposta à demanda dos alunos de uma determinada escola. [...] A Lei nos parece clara, reafirmando o caráter leigo do Estado e a necessidade de formação religiosa aos cuidados dos representantes reconhecidos pelas próprias igrejas. (CONSELHO NACIONAL DE EDUCAÇĀO, 1997). ${ }^{9}$

Com relação ao ônus financeiros, conclui o Parecer:

Esta segunda interpretação impóe algumas definições, em especial quanto ao financiamento desta atividade na escola pública. Mesmo que a LDB não o declarasse, não poderia haver ônus para os cofres públicos, por três motivos:

a) haveria violação do art. 19 da CF que veda a subvenção a cultos religiosos e a igrejas;

b) criaria um tratamento desigual do Estado com relação às diversas igrejas, porque a subvençáo seria desproporcional à demanda. Como o professor seria pago por hora curricular de trabalho, um ou dois alunos de uma religiáo demandariam o mesmo gasto do Estado do que trinta ou quarenta de outra, já que a lei garante a confessionalidade e a opção dos alunos;

c) finalmente, havendo disposiçáo de pagamento pelo Estado, poder-se-ia chegar ao absurdo de o ensino religioso para dezenas de denominaçóes diferenciadas com demanda

8 Disponível em: <www.nepp-dh.ufrj.br/ole/textos/er_escolas_publicas.doc>.

9 Idem. 
na escola ser mais oneroso que o ensino de outras matérias com maior carga horária. (CONSELHO NACIONAL DE EDUCAÇÃO, 1997). ${ }^{10}$

A lei n. 9.475/97, alterando o art. 33, trouxe substanciais mudanças: não se lê mais o sem ônus para os cofres públicos; o ensino religioso passou a constar como parte integrante da formação básica do cidadão e há vedação de qualquer forma de

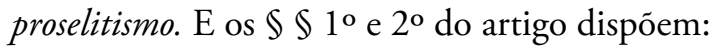

$\$ 1^{\circ}$ Os sistemas de ensino regulamentaráo os procedimentos para a definiçáo dos conteúdos do ensino religioso e estabelecerão as normas para a habilitação e admissão dos professores.

$\$ 2^{\circ}$ Os sistemas de ensino ouvirão entidade civil, constituída pelas diferentes denominaçóes religiosas, para a definição dos conteúdos do ensino religioso. (BRASIL, 1997). ${ }^{11}$

Vale dizer, a regulamentação dos conteúdos e da habilitação de professores passou a ser competência de cada ente federativo, conforme suas atribuiçóes legais, os quais, para efeito da definição dos conteúdos devem ouvir uma entidade civil multirreligiosa. ${ }^{12}$

Após a alteração em 1997, o Conselho Nacional de Educação, por meio de seu Conselho Pleno, exarou o Parecer CNE/CP n. 97/99, que buscou respeitar os enunciados dos parágrafos do artigo modificado que tocam ao princípio federativo. Assim:

Nesta formulação, a matéria parece fugir à competência deste Conselho, pois a questão da fixação de conteúdos e habilitação e admissão dos professores fica a cargo dos diferentes sistemas de ensino. Entretanto, a questáo se recoloca para o Conselho e, especialmente, para esta Câmara, no que diz respeito à formação de professores para o ensino religioso, em nível superior, no Sistema Federal de Ensino. Têm chegado ao Conselho solicitaçóes de autorização e reconhecimento de cursos de licenciatura

10 Disponível em: <www.nepp-dh.ufrj.br/ole/textos/er_escolas_publicas.doc>.

11 Disponível em: <http://www.planalto.gov.br/ccivil_03/leis/L9475.htm>.

$12<$ Cf. <www.fonaper.org.br>. 
em ensino religioso. (CONSELHO NACIONAL DE EDUCAÇÃO, 1999a). ${ }^{13}$

Voltando-se para normatizar o sistema federal de educação, o Parecer ressalva a autonomia federativa:

Em primeiro lugar, deve-se considerar que, atribuindo a lei aos diferentes sistemas de ensino, não só a definição dos conteúdos do ensino religioso, mas também as normas para habilitação e admissão dos professores, é impossível prever a diversidade das orientaçóes estaduais e municipais e, assim, estabelecer uma diretriz curricular uniforme para uma licenciatura em ensino religioso que cubra as diferentes opçóes. Em segundo lugar, precisamos reconhecer que a Lei no 9475 não se refere à formação de professores, isto é, ao estabelecimento de cursos que habilitem para esta docência, mas atribui aos sistemas de ensino tão somente o estabelecimento de normas para habilitação e admissão dos professores. Supóe-se, portanto, que esses professores possam ser recrutados em diferentes áreas e deveriam obedecer a um processo específico de habilitação. Não se contempla, necessariamente, um curso específico de licenciatura nesta área, nem se impede que formação possa ser feita por entidades religiosas ou organizaçóes ecumênicas. Considerando estas questóes é preciso evitar que o Estado interfira na vida religiosa da populaçáo e na autonomia dos sistemas de ensino. (CONSELHO NACIONAL DE EDUCAÇÃO, 1999a, grifos nossos). ${ }^{14}$

E conclui:

Esta parece ser, realmente, a questáo crucial: a imperiosa necessidade, por parte do Estado, de náo interferir e, portanto, não se manifestar sobre qual o conteúdo ou a validade desta ou daquela posição religiosa e, muito menos, de decidir sobre o caráter mais ou menos ecumênico de conteúdos propostos. Menos ainda deve ser colocado na posiçáo de arbitrar quando, optando-se por uma

13 Disponível em: <www.nepp-dh.ufrj.br/ole/textos/er_escolas_publicas.doc>.

14 Disponível em: <www.nepp-dh.ufrj.br/ole/textos/er_escolas_publicas.doc>. 
posição ecumênica, diferentes seitas ou igrejas contestem os referidos conteúdos da perspectiva de sua posição religiosa, ou argumentem que elas não estão contempladas na programação. Por estas razóes, parece-nos impossível, sem ferir a necessária independência entre Igreja e Estado, estabelecer uma orientação nacional uniforme que seria necessária para a observância dos processos atuais de autorização e reconhecimento. (CONSELHO NACIONAL DE EDUCAÇÃO, 1999a). ${ }^{15}$

Com isso, o CNE abdicou de explicitar diretrizes, seja para a questão dos ônus, seja para a formação de professores, deixando a critério dos sistemas estaduais e municipais o encaminhamento de tais dimensóes. ${ }^{16}$ Assim, importa a consulta tanto à normatização trazida pelas secretarias de educação como também dos Conselhos de Educaçáo. ${ }^{17}$

Nesse Parecer, vale recuperar a distinção nele posta em que se diferencia a formação da habilitação. A formação é aquela qualificação que se adquire ao término de um curso de ensino superior autorizado e expresso em um diploma em vista de uma presença no âmbito profissional. Já a habilitação é o reconhecimento de uma capacidade por uma autoridade pertinente compatível com uma atividade qualquer. Pode ser o registro em um órgão corporativo (supondo, no caso, formação prévia) ou uma carteira de motorista (não supóe formação de ensino superior). Assim, toda a formação prevê uma habilitação, mas nem toda habilitação supóe uma formação de ensino superior. No caso do ensino religioso, dada a sua natureza peculiar, em outras legislações, essa habilitação era dada por uma autoridade eclesiástica. O Parecer não impede que formação possa ser feita por entidades religiosas ou organizaçóes ecumênicas ... evitando que o Estado interfira na vida religiosa da população e na autonomia dos sistemas de ensino.

Mas, no âmbito do sistema federal de educação, o Parecer indica que tal formação não se possa ser ofertada em cursos de licenciatura, seja pelo Parecer de 1997, seja pelo de 1999. O que se confirma pelo Parecer CNE/CP n.

15 Idem.

16 Sobre ensino religioso e carga horária, cf. Parecer CNE/CEB n. 05/97; 12/97 e 16/98. Sobre um Conselho Municipal de ensino religioso, cf. Parecer CNE/CEB n. 26/2007. Já sobre a presença do ensino religioso na Base Nacional Comum Curricular, cf. Parecer CNE/CEB n. 07/2010, que trata das Diretrizes Nacionais Curriculares Gerais da Educação Básica e que inclui o ER na BNCC. A atual proposta do MEC sobre a BNCC, enviada ao CNE, não abrange o ensino religioso.

17 Cf. <www.edulaica.net.br o link relativo aos Pareceres dos Conselhos Estaduais de Educação a esse respeito>. 
1.105/99, que apoia o parecer da SESU sobre solicitação de licenciatura em ensino religioso:

Tendo em vista deliberação do Conselho no sentido que não serão autorizados cursos destinados à formação de professores para o ensino religioso, entendeu o Relator que não seria possível apreciar a solicitaçáo nos termos propostos, e que, caso fosse do seu interesse, a Instituição requerente poderia adequar sua pretensão, de modo a atender aos pressupostos definidos no Parecer CES 241/99, transformando o projeto com vistas à autorizaçáo de um curso de Bacharelado em Teologia. (CONSELHO NACIONAL DE EDUCAÇÃO, 1999b, grifos nossos). ${ }^{18}$

Assim, pode haver uma espécie de antinomia, em termos de fundamentação, entre a orientação dada ao sistema federal de educação e os sistemas de educação dos entes federativos. Dada a autonomia que os Estados possuem na oferta de um ensino superior público estadual, poderiam eles abrir uma licenciatura em ensino religioso? No caso, os Estados-membros não estariam interferindo em um campo próprio das entidades religiosas? Isso requer, pois, tomada de posição do Conselho Nacional de Educação não só reiterando, explicitando a recusa a todo e qualquer proselitismo (algo já presente no art. 33), como também diretrizes para a rede federal de ensino que possam servir de balizas para os demais entes federativos de sorte a evitar antinomias em relação ao mesmo assunto, no caso, a formação de professores.

Além disso, há que se considerar a tradição da facultatividade da matrícula na oferta obrigatória dessa disciplina. O fato de a alteração do art. 33 haver posto o ensino religioso como integrante da formação básica do cidadão impóe uma hermenêutica até mesmo pelo Supremo Tribunal Federal. Ficou algo híbrido e até certo ponto, antinômico ao princípio da facultatividade (que é constitucional, antes de ser infraconstitucional). Como ser inerente à formação básica e ser opcional para o aluno?

Com isso, o CNE poderia se valer do art. $24, \$ 1^{\circ}$, pelo qual, no âmbito da legislação concorrente, a competência da União limitar-se-á a estabelecer normas gerais. Com a palavra, o Conselho Nacional de Educação!

O princípio da laicidade é congruente com o espírito científico, pois o que faz o avanço do conhecimento não é uma verdade já estabelecida. Essa pode ser assumida no âmbito da fé do indivíduo e nos espaços da sociedade civil, com todas as garantias do direito de crença e de culto. O que faz avançar o conhecimento científico é a dúvida, é a crítica e o desenvolvimento de uma metodologia que se caracteriza pela

Disponível em: <http://portal.mec.gov.br/cne/arquivos/pdf/1999/pces1105_99.pdf>. 
circulação do saber crítico, pelo debate e diálogo entre diversos pontos de vista. É nesse sentido, à luz do desenvolvimento próprio do saber científico que, em qualquer universidade, a formação docente qua talis é laica.

\section{Referências}

BOBBIO, Norberto; VIROLI, Maurizio. Diálogo em torno da República: os grandes temas da política e da cidadania. Rio de Janeiro: Campus, 2002.

BRASIL. Constituição da República Federativa do Brasil, 1988. Versão eletrônica. Disponível em: http://www.planalto.gov.br/ccivil_03/constituicao/ constituicao.htm>. Acesso em: 3 set. 2017.

BRASIL. Lei de Diretrizes e Bases da Educaçáo (LDB). Lei no. 9.394, de 20 de dezembro de 1996. Estabelece as diretrizes e bases da educação nacional. Disponível em: <http://www.planalto.gov.br/ccivil_03/leis/L9394.htm>. Acesso em: 3 set. 2017.

BRASIL. Lei no 9.475, de 22 de julho de 1997. Dá nova redação ao art. 33 da Lei $\mathrm{n}^{\circ}$ 9.394, de 20 de dezembro de 1996, que estabelece as diretrizes e bases da educação nacional. Disponível em: <http://www.planalto.gov.br/ccivil_03/leis/ L9475.htm>. Acesso em: 3 set. 2017.

BRASIL. Ministério da Educação. Resolução no 2, de $1^{\circ}$ de julho de 2015. Define as Diretrizes Curriculares Nacionais para a formaçáo inicial em nível superior (cursos de licenciatura, cursos de formação pedagógica para graduados e cursos de segunda licenciatura) e para a formação continuada. Brasília, DF, 2015. 16p. Disponível em: <http://pronacampo.mec.gov.br/images/pdf/res_ cne_cp_02_03072015.pdf>. Acesso em: 3 set. 2017.

CARVALHO, José Sérgio. Podem a Ética e a Cidadania serem ensinados? ProPosiçóes - Unicamp, FE, v. 13, p. 157-168, set/dez 2002.

CONSELHO NACIONAL DE EDUCAÇÃO. Parecer CP 05/97. Dispõe sobre a formação de professores para o Ensino Religioso nas escolas públicas de ensino fundamental. Brasília, DF, 1997. Disponível em: <www.nepp-dh.ufrj.br/ ole/textos/er_escolas_publicas.doc>. Acesso em: 3 set. 2017.

CONSELHO NACIONAL DE EDUCAÇÃO. Parecer CP 97/99. Formação de professores para o Ensino Religioso nas escolas públicas de ensino fundamental. Brasília, DF, 1999a. Disponível em: <www.nepp-dh.ufrj.br/ole/textos/er_ escolas_publicas.doc>. Acesso em: 3 set. 2017. 
CONSELHO NACIONAL DE EDUCAÇÃO. Parecer 1.105/99. Autorização (projeto) para funcionamento do curso de Licenciatura em Ensino Religioso. Brasília, DF, 1999b. Disponível em: <http://portal.mec.gov.br/cne/arquivos/ pdf/1999/pces1105_99.pdf>. Acesso em: 3 set. 2017.

CUNHA, Luiz Antônio. O veto transverso de FHC à LDB: o ensino religioso nas escolas públicas. Educação e Pesquisa, São Paulo, v. 43, n. 3, jul/set. 2016.

CURY, Carlos Roberto Jamil. Laicidade e Religião. In: BAPTISTA, Paulo Agostinho Nogueira; PASSOS, Mauro; SILVA, Wellington Teodoro (Org.). O Sagrado e o Urbano: diversidade, manifestações e análise. São Paulo: Paulinas, 2008. p.127-134.

CURY, Carlos Roberto Jamil. Ensino Religioso na escola pública: o retorno de uma polêmica.

Revista Brasileira de Educaçáo, Campinas, n. 27, p. 183-191, 2004.

CURY, Carlos Roberto Jamil. A educaçáo na revisão constitucional de 19251926. Bragança Paulista: EDUSF, 2003. 142 p.

SARLET, Ingo Wolfgang. Dignidade da Pessoa Humana e Direitos Fundamentais na Constituiçáo Federal de 1988. Porto Alegre: Livraria do Advogado, 2001. 